\title{
Karolina Echaust
}

karolina.e84@gmail.com

https://orcid.org/0000-0002-6644-7580

Instytut Etnologii i Antropologii Kulturowej

Wydział Historyczny

Uniwersytet im. Adama Mickiewicza w Poznaniu

\section{Bartnictwo w kontekście ekologii kulturowej i ochrony niematerialnego dziedzictwa kulturowego - refleksje po badaniach pilotażowych}

\author{
Tree Beekeeping in the Context of Cultural Ecology \\ and the Protection of Intangible Cultural Heritage \\ - Reflections after the Research Reconnaissance
}

\begin{abstract}
Streszczenie: Artykuł prezentuje analizę badań pilotażowych przeprowadzonych w październiku 2018 roku w Puszczy Augustowskiej. Celem pilotażu było „wejście w teren” oraz zebranie materiału empirycznego poprzez przeprowadzenie etnograficznych badań terenowych. Podczas kilkudniowego pobytu miałam możliwość uczestniczenia w warsztatach bartniczych. Efektem wyjazdu terenowego jest pozyskany materiał źródłowy, dokumentacja fotograficzna oraz filmowa, dziennik badań terenowych, wywiady nieustrukturyzowane. Niniejszy artykuł ma na celu analizę zebranego materiału badawczego oraz refleksję nad metodologią etnograficznych penetracji terenowych. Zwraca również uwagę na metody i techniki badawcze, które sprawdziły się w terenie oraz takie, które nie przyczyniły się do osiągnięcia oczekiwanych rezultatów. W artykule przedstawiona jest też analiza związków metodologii z tematem i problematyką prowadzonych badań etnograficznych.
\end{abstract}

Slowa klucze: bartnictwo, niematerialne dziedzictwo kulturowe, ekologia kulturowa, dziedzictwo kulturowe, etnograficzne badania terenowe, metodologia

Summary: The article presents an analysis of research reconnaissance carried out in October 2018 in the Augustowska Primeval Forest. The purpose of the reconnaissance was to "enter the field", so to speak, and to collect source material during a few days' stay, I had the opportunity to participate in beekeeping workshops. The result of this field trip is the source material, photographic and film documentation that have been acquired, a field research journal, and unstructured interviews. This article aims to present the initial analysis of the pilot research material and the methods of developing the collected material and results. It also contains reflections on the methodology of ethnographical field penetration and a discussion of research methods and techniques that worked well in the field and those that did not contribute to the expected results. The author also reviews the relationship between the methodology and the subject and issues of her ethnographical research.

Key words: tree beekeeping, intangible cultural heritage, cultural ecology, cultural heritage, ethnography fieldwork, methodology 


\section{Wprowadzenie}

Ochrona niematerialnego dziedzictwa kulturowego jest aktualnym tematem poruszanym w naukach humanistycznych. W Polsce w 2016 roku bartnictwo zostało wpisane na Krajowa listę niematerialnego dziedzictwa kulturowego w ramach przyjętej przez UNESCO w 2003 roku Konwencji w sprawie ochrony niematerialnego dziedzictwa kulturowego. Konwencja została ratyfikowana przez Polskę w 2011 roku. Wyróżnienie bartnictwa $\mathrm{w}$ formie sformalizowanego zapisu przyczyniło się do zwiększenia zainteresowania pszczelarstwem, poszerzając z roku na rok krąg nowych adeptów sztuki dziania barci. W październiku 2018 roku uczestniczyłam w warsztatach bartniczych, nauczyłam się, jak dziać kłodę bartną oraz gromadziłam materiał empiryczny do pracy doktorskiej dotyczący działalności organizacji bartniczej. Artykuł jest wstępną analizą zebranego materiału empirycznego oraz refleksją nad wynikami badań.

\section{Cel i metodologia badań}

Etnograficzne badania pilotażowe prowadziłam w dniach 12-14 października 2018 roku w miejscowości Lipiny, położonej na obszarze Puszczy Augustowskiej, w gminie Płaska, w powiecie augustowskim. „VII Warsztaty Bartnicze Bractwa Bartnego w Puszczy Augustowskiej" zorganizowała organizacja pozarządowa Bractwo Bartne / Fratrum Mellicidarum. Celem mojego wyjazdu było „wejście do środowiska” (Hammersley, Atkinson 2000: 65) oraz uzyskanie zgody od przedstawicieli organizacji bartnej na prowadzenie badań, podczas których chciałam zastanowić się nad współczesnymi tradycjami bartniczymi jako zjawiskiem wieloaspektowym, będącym jedną $\mathrm{z}$ form ochrony niematerialnego dziedzictwa kulturowego. W kręgu moich zainteresowań znalazły się takie tematy, jak odtwarzanie, adaptacja i upowszechnianie tradycji bartniczych na potrzeby lokalnych społeczności. Oprócz powyższych istotna jest dla mnie także płaszczyzna ochrony niematerialnego dziedzictwa kulturowego, rozumiana jako „(..) reprezentowanie interesów (...) osób zrzeszonych w organizacjach” (Brzezińska 2009: 164). Natomiast jedno z kluczowych pytań badawczych brzmi: czy możemy mówić o współczesnych tradycjach bartniczych, czy tylko o odtwarzaniu nieistniejącego świata? (Brzezińska 2009). Nieobojętna jest mi również płaszczyzna relacji człowiek - zwierzę, a także kwestia zarządzania zasobami naturalnymi w ujęciu ekologii kulturowej. Ujmując tradycje bartnicze w relacji do ekosystemów leśnych, nie można zapominać o tym, że:

same lasy, zmieniają się kształtując, przeobrażając i wpływając na percepcję lasów, manifestując się w rozmaitych punktach widzenia, dostarczając narzędzi do zrozumienia relacji pomiędzy ludźmi i środowiskiem. Problematyka antropologicznych studiów leśnych zakłada, że są one 
w stanie współuczestniczyć w dostarczaniu wiedzy, która w przyszłości może pomóc w planowaniu zarządzania lasami, rozwiązywaniu narastających wokół nich sporów, ale także podkreśla złożoność powiązań między lasem a jego użytkownikami (Konczal 2017: 21).

Niniejszy artykuł dotyczy aspektów ochrony niematerialnego dziedzictwa kulturowego w myśl Konwencji UNESCO $w$ sprawie ochrony niematerialnego dziedzictwa kulturowego. Zgodnie z założeniami Konwencji ochronę rozumiem

jako środki mające na celu zapewnienie przetrwania niematerialnego dziedzictwa kulturowego, w tym jego identyfikację, dokumentację, badanie, zachowanie, zabezpieczenie, promowanie, wzmacnianie i przekazywanie, w szczególności poprzez edukację formalną i nieformalną, jak również rewitalizację różnych aspektów tego dziedzictwa (Konwencja UNESCO, Dz. U. nr 172, poz. 1018, art. 2, pkt. 3).

Przedstawiciele organizacji bartniczych „odtwarzają” dawne praktyki bartnicze, a przejawem tych praktyk jest tworzenie nowych, „współczesnych” tradycji bartniczych, do których zaliczyć możemy organizowane cyklicznie warsztaty bartnicze.

W badaniach pilotażowych nie zakłada głębszego wniknięcia w badaną społeczność. $\mathrm{Na}$ tym etapie procesu badawczego istotne jest sprecyzowanie problemów i pytań badawczych, a także ,przetestowanie oraz ocena narzędzia, które ma być wykorzystane w badaniu zasadniczym" (Grzeszkiewicz-Radulska 2012: 113). Zanim badacz wyruszy w teren, kluczowa staje się analiza źródeł zastanych i wywołanych, zebranych we wcześniejszych badaniach.

Bartnictwo doczekało się wielu opracowań, w których najczęściej ujmowane było w ramy historyczne, jako zjawisko minione, związane z przeszłością, ponadto skupiano się na opisie tradycji bartnych w Polsce i na świecie (Barański 1979, Blank-Weissberg 1937, Burszta 1954, Kargul 2011, Karpiński 1948, Keczyński 2017, Kielak 2004, Kuciński 2017, Kuczyńska 2004, Rafacz 1938, Rogoziński 2015, Siudowska-Myzykowa 1960, Szymusik 2006, Wróblewski 1987, 1991, 1997, 1998, 2009, Żukowski 1965). Prowadzone przez mnie badania, oprócz kontekstu historycznego, dotyczą bartnictwa w kontekście ekologii kulturowej. W naukach humanistycznych tematyka społeczno-przyrodnicza podejmowana była przez badaczy takich jak Mariusz Ciszek (2009), Kirsten Hastrup (2014), Tim Ingold (1990, 2011), Agata Konczal (2017), Katarzyna Wala (2016), Jacek Żukowski (2011). Biorąc pod uwagę współzależności pomiędzy człowiekiem a pszczołą, na uwagę zasługuje publikacja amerykańskiej badaczki Kori Nadine Armstrong Beeing with Bees: An Anthropological Study on Human-Animal Relations i Southern Beekeeping (Armstrong 2016). Autorka odnosi się do relacji między pszczelarzami a rodzinami pszczelimi, wskazując na zależności łączące świat natury i kultury. Podstawą do napisania książki były dla niej etnograficzne badania 
terenowe. Armstrong zaintrygowana była tym, w jaki sposób pszczelarze postrzegają świat rodzin pszczelich. Swoje dane zbierała stosując jawną obserwację uczestniczącą. Publikacja Armstrong wpłynęła na ukierunkowanie moich zainteresowań badawczych i przyczyniła się do podjęcia przeze mnie tematu bartnictwa z perspektywy społeczno-kulturowej. Badania pilotażowe wśród pszczelarzy i bartników ukazały mi fascynujące światy ludzi, pszczół i relacji między nimi, co utwierdziło mnie w przekonaniu, jak ważna jest ochrona współczesnych praktyk „chodzenia koło barci” (Wróblewski 1997: 64).

Równolegle do analizy źródeł zastanych i wywołanych, prowadzę obserwację dyskursu w przestrzeni medialnej. Oczywiście tego rodzaju badania stanowią wyłącznie tło zasadniczych badań terenowych. W artykułach takich jak Bartnictwo wraca do polskich lasów (Nauka w Polsce 2017), Wielki powrót barci do polskich lasów (Ogródinfo.p1 2017), Powrót do tradycji. W lasach coraz więcej dzikich pszczót (Kaien, Adom 2016) zwraca się uwagę na to, że bartnictwo to odradzająca się i podkreślająca polskość tradycja. Dostrzegam, że w projektach opisywanych w sieci, a realizowanych przez instytucje państwowe, organizacje pozarządowe oraz inicjatywy społeczne, bartnictwo funkcjonuje jako „wyróżnik polskości”. Akcentowanie faktu, że „Polska jako jedyny kraj Unii Europejskiej podjęła próbę przywrócenia na swoim terenie bartnictwa, jako szansę ochrony przyrody i staropolskiej tradycji” (Madras-Majewska 2012: 33-38) jest częstym zabiegiem medialnym. Po analizie wybranych artykułów stwierdzam, że bartnictwo urosło do rangi „,mitu narodowego, w którym jest ono nieodłączną częścią lasu (polskiego) i współtworzy las będący (polskim) dziedzictwem kulturowym tylko dzięki strażnikom tego dziedzictwa (bartnikom, leśnikom)" (Konczal 2017: 66).

Podczas rekonesansu badawczego zebrałam materiał empiryczny pozwalający na przeprowadzenie wstępnych analiz, podsumowań i refleksji. Literatura przedmiotu - z jednej strony, i obserwacja dyskursu współczesnych tradycji bartniczych w przestrzeni medialnej - z drugiej, to pierwszy etap moich etnograficznych badań terenowych. Kolejnym etapem była penetracja terenowa i doświadczenie „pierwszych dni w terenie” (Hammersley, Atkinson 2000: 64) wraz z zastosowaniem technik badawczych, takich jak jawna obserwacja uczestnicząca lub częściowo uczestnicząca oraz przeprowadzenie nieustrukturyzowanych wywiadów jakościowych. Podczas rekonesansu badawczego prowadziłam dziennik badań terenowych zarówno w wersji papierowej, jak i elektronicznej, stanowiący dla mnie ważne źródło wiedzy etnologicznej (obserwacja, rejestracja, refleksja, opis). Takie kompleksowe podejście do kwestii współczesnych tradycji bartniczych, w kontekście ekologii kulturowej i ochrony niematerialnego dziedzictwa kulturowego, jest konieczne do tego, aby spojrzeć na badane zjawisko z perspektywy 
społeczno-kulturowej. Podczas kilkudniowego pobytu przeprowadziłam wywiady nieustrukturyzowane z przedstawicielami organizacji bartnej i uczestnikami warsztatów bartniczych oraz zgromadziłam dokumentację fotograficzną (wykonałam 231 zdjęć) i nagrania dźwiękowe (10 nagrań). Materiał wizualny podzieliłam na ten dotyczący tematyki warsztatów (wprowadzenie teoretyczne, zagadnienia związane z bezpieczeństwem, dzianie kłody bartnej, posługiwanie się leziwem, wyjazd na wciągnie kłody bartnej, przegląd zasiedlonych barci i kłód bartnych na obszarze działalności Bractwa Bartnego, wykończenie kłód bartnych i pakowanie ich do aut, zakończenie kursu') oraz na ten opisujący poszczególne dni warsztatów (piątek, sobota, niedziela).

Pierwszego dnia warsztatów, w piątek wieczorem, kiedy miała miejsce zbiórka uczestników warsztatów i wspólna kolacja w Leśniczówce Lipiny, przedstawiając się wyjaśniłam cel mojego pobytu na warsztatach. Od pierwszego dnia „bycia w terenie” przyjęłam rolę badaczki - etnografki - antropolożki kulturowej. Zależało mi na tym, aby w sposób jasny określić intencję mojego pobytu na warsztatach. W realizacji tego celu posłużyłam się również techniką wizytówki. Ostatniego dnia warsztatów, w momencie oczekiwania uczestników na śniadanie, wręczyłam wszystkim wizytówki, na których znajdowały się moje imię i nazwisko, afiliacja, dane kontaktowe (e-mail, numer telefonu), temat pracy doktorskiej oraz krótkie wyjaśnienie celu moich badań. Wydrukowałam je w kolorze czarno-białym, a wielkość każdej z nich stanowiła jedną czwartą kartki A4. Dlaczego ostatniego, a nie pierwszego dnia spotkania? Po pierwsze, był to sposób podsumowania mojego pobytu na warsztatach. Po drugie, nie pozostałam anonimowa dla uczestników warsztatów i przedstawicieli organizacji bartnej. Po trzecie, ułatwiło mi to kontakt w celu zdobycia dalszych informacji. Zgoda członków Bractwa Bartnego na prowadzenie badań terenowych była dla mnie wielkim sukcesem pilotażu, tym bardziej, że wyjazd był krótkim pobytem w zupełnie obcym środowisku i wśród nieznanych mi do tej pory osób. „Wejście do środowiska” zakończyło się sukcesem, dlatego też uważam, że jawna obserwacja uczestnicząca jest tą, która powinna stanowić trzon etnograficznych badań terenowych, pozbawiając tym samym etnologów czy antropologów kulturowych „badawczego cienia” (Kalinowska 2013: 59). To właśnie na pierwszym etapie penetracji terenowej tak ważne jest wzajemne zaufanie w relacji badacz-badany, a osiągnąć możemy to poprzez otwartość i szczerość.

\footnotetext{
${ }^{1}$ Podstawą do opracowania materiału wizualnego był harmonogram „VII Warsztatów Bartniczych Bractwa bartnego w Puszczy Augustowskiej” (Leśniczówka Lipiny), otrzymany od Bractwa Bartnego drogą mailową.
} 


\section{Współczesne tradycje bartnicze}

Dla etnograficznych badań terenowych na temat współczesnych tradycji bartniczych istotne jest ujęcie ich z perspektywy współzależności kulturowo-środowiskowych. We wspomnianym kontekście natura nabiera znaczenia w odniesieniu do kultury, gdyż „człowiek jest zwierzęciem zawieszonym w sieci znaczeń, którą sam utkał (...) zaś kultura nakłada arbitralną ramę znaczeń symbolicznych na rzeczywistość" (Ingold 2000: 172, 178). Zamierzonym przeze mnie efektem badań terenowych będzie próba wypracowania modelu badawczego, stanowiącego odpowiedź na potrzebę nowego spojrzenia na relacje pomiędzy człowiekiem (bartnik), środowiskiem (ekosystem leśny - puszcza, las) a zwierzęciem (pszczoła) z perspektywy nauk humanistycznych. Dla osiągnięcia tego efektu niezbędne jest prowadzenie penetracji terenowych, wyjazdów studyjnych i badawczych, czyli jak najczęstsze „bycie w terenie”. Pilotażowe badania terenowe są jednym z etapów procesu badawczego i umożliwiają dokonanie wstępnych analiz i refleksji, co nierzadko ma wpływ na dalsze etapy pracy naukowej. Poprzez zastosowanie metody triangulacji, narzędzia badawcze, wykorzystane przeze mnie w czasie wyjazdów terenowych, powinny umożliwić analizę materiału źródłowego oraz kontrolę własnych poczynań, co stworzy podstawę do rzetelnego opracowania i opublikowania wyników badań.

Na potrzeby badań termin bartnictwo zastąiłam sformułowaniem „współczesne tradycje bartnicze" z tego względu, że obecnie mówimy o odtwarzaniu techniki bartniczej i tradycji z nią związanych. Bartnictwo, jako forma użytkowania lasu, zakończyło się wraz z wprowadzanymi sukcesywnie regulacjami prawnymi i zostało wyparte przez rolnictwo, czego następstwem było przeniesienie kłód bartnych do gospodarstw. Efektem tego był rozwój pasiecznictwa, a następnie pszczelarstwa (Barański 1979: 62-63). Obecnie odtwarzanie tego, wydawałoby się zapomnianego sposobu chowu pszczół w barciach i kłodach bartnych, jest możliwe dzięki działaniom instytucji i organizacji, takich jak Lasy Państwowe, związki pszczelarskie, organizacje pozarządowe, w tym stowarzyszenia i fundacje. Działalność bartnicza w dużej mierze zależy od funduszy unijnych, samorządowych czy gminnych, które są przekazywane na działania edukacyjne w ramach zapisów statutowych wybranych organizacji i instytucji. Od pewnego czasu zainteresowanie bartnictwem zauważa się również wśród pszczelarzy, którzy coraz chętniej w pasiekach stawiają kłody bartne, aby samemu zrewidować opinię na temat "pszczelarstwa leśnego”. Dowodzą tego moje badania pilotażowe w Lipinach, podczas których prowadziłam rozmowy z pszczelarzami uczestniczącymi w warsztatach bartniczych. 
W statucie organizacji bartnej czytamy, że jednym z jej celów jest „promowanie działań i zachowań proekologicznych, szczególnie odtwarzanie i rozwój tradycyjnego bartnictwa oraz odtwarzanie, rozwój i ochrona populacji pszczół dziko żyjących”, a także „prowadzenie działalności edukacyjnej oraz naukowej oraz działalności wspomagającej rozwój wspólnot i społeczności lokalnych”2. Realizacja założeń statutowych przyczynia się do odtwarzania współczesnych tradycji bartniczych. Podczas warsztatów wszystko „dzieje się” wokół kłód bartnych. Uczestnicy o nich rozmawiają, planują wykonanie kłody bartnej, zmieniają wcześniej ustalone koncepcje dziania, udoskonalają swoje pomysły, aby w efekcie zabrać gotową kłodę do domu. Celem warsztatów jest nauka dziania kłody bartnej, z wykorzystaniem współczesnych narzędzi (piła spalinowa), jak również tych nawiązujących do dawnego rzemiosła, jak ciosło, piesznia, skobliczka, barta. Po zakończonych warsztatach uczestnicy pakują kłody do samochodów i transportują je nierzadko setki kilometrów. O posiadaniu podstawowej wiedzy z zakresu bartnictwa zaświadcza akt uczestnictwa w warsztatach bartniczych, wręczony każdemu uczestnikowi i wieńczący spotkanie bartników w Puszczy Augustowskiej.

$\mathrm{Z}$ poczynionych do tej pory analiz różnorodnych źródeł wynika, że edukacja jest ważnym czynnikiem umożliwiającym funkcjonowanie wielu organizacji skupionych wokół szeroko rozumianych współczesnych tradycji bartniczych. Wymiar edukacyjny działań organizacji bartnej przejawia się w prowadzeniu warsztatów, organizowaniu konferencji, pogadanek, seminariów czy imprez plenerowych, na których chętni mogą nauczyć się, jak dziać kłodę bartną czy wspiąć się na drzewo za pomocą leziwa. Działania edukacyjne są formami ochrony niematerialnego dziedzictwa kulturowego.

W trakcie badań każdego dnia towarzyszyła mi refleksja o społecznym zaangażowaniu w realizowany projekt, co pozwoliło spojrzeć na warsztaty bartnicze jako na jedną z form ochrony niematerialnego dziedzictwa kulturowego. W związku z powyższym moje dotychczasowe doświadczenia terenowe przyczyniły się do skonstruowania nowych pytań badawczych. Kto podczas warsztatów bartniczych jest edukującym, a kto edukowanym? W jaki sposób aktywność badacza przejawia się w momencie uczestniczenia w warsztatach bartniczych, a więc bycia - z jednej strony - ich uczestnikiem, a z drugiej - naukowcem? Pomocne w udzieleniu odpowiedzi na postawione wyżej pytania będą dwa zestawienia, które poczyniłam podczas analizy danych empirycznych. Pierwsze zestawienie zilustrowane jest $\mathrm{w}$ formie tabeli (Tab. 1).

\footnotetext{
${ }^{2}$ Informacje zaczerpnięte z dokumentu „Statut fundacji: Bractwo Bartne” (http://bartnictwo.com/pl/wp-content/uploads/sites/3/2016/07/statut-fundacji.pdf).
} 
Tabela 1. Porównanie perspektywy badaczki i organizacji

\begin{tabular}{|c|c|}
\hline $\begin{array}{l}\text { Perspektywa badaczki, czyli ,ja” jako etno- } \\
\text { lożka i uczestniczka warsztatów bartniczych }\end{array}$ & $\begin{array}{l}\text { Perspektywa organizacji, czyli organizato- } \\
\text { rzy warsztatów bartniczych }\end{array}$ \\
\hline \multirow{6}{*}{$\begin{array}{l}\text { Cel: badania terenowe } \\
\text { Realizacja: jawna obserwacja uczestnicząca, } \\
\text { wizytówki, notatki, zgoda na badania } \\
\text { - moje zaangażowanie i aktywność (dzianie } \\
\text { kłody bartnej) } \\
\text { - moje badania w oczach innych }\end{array}$} & 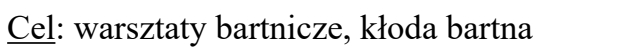 \\
\hline & Realizacja: nauka uczestników dziania kłody \\
\hline & \\
\hline & $\begin{array}{l}\text { leziwa, dążenie do zachowania rodzimego } \\
\text { gatunku nszczoły środkowoeuroneiskiej. }\end{array}$ \\
\hline & linii augustowskiej / linii północnej \\
\hline & $\begin{array}{l}\text { - wymiar edukacyjny, promocyjny i upo- } \\
\text { wszechniający działalności organizacji } \\
\text { bartniczych }\end{array}$ \\
\hline Punkty wspólne: & Punkty wspólne: \\
\hline $\begin{array}{l}\text { - wymiana informacji na poziomie badacz- } \\
\text {-badany }\end{array}$ & $\begin{array}{l}\text { - wymiana informacji na poziomie badacz- } \\
\text {-badany }\end{array}$ \\
\hline - relacje, wiedza, umiejętności & - relacje, wiedza, umiejętności \\
\hline - zaufanie, etyka & - zaufanie, etyka \\
\hline
\end{tabular}

Drugie zestawienie omówiłam na przykładzie trzech perspektyw i nazwałam je badacz ,(nie)zaangażowany w terenie”:

1. perspektywa - ,etnolog edukowany”, czyli moje „,bycie w terenie” (jako uczestniczka warsztatów oraz osoba poznająca tajniki dziania barci i ekologii pszczół);

2. perspektywa - „etnolog edukujący”, czyli moja obecność na warsztatach i wpływ moich badań na prowadzących i pozostałych uczestników zajęć;

3. perspektywa wzajemnych powiązań pomiędzy edukowanymi a edukującymi, czyli przenikające się płaszczyzny badacz-badany i badany-badacz. Bycie badaczką (nie)zaangażowana społecznie wymusza na mnie sytuacja, w której równolegle prowadzę badania wśród społeczności bartników oraz jestem uczestniczką warsztatów. Jak wynika z powyższych zestawień zarówno organizatorzy warsztatów, jak i badaczka podejmują działania edukacyjne na poziomie badacz (uczę się teorii i praktyki dziania kłody bartnej) - badany (dowiaduje się między innymi tego, czym jest etnologia, antropologia kulturowa, ekologia kulturowa). W jednej z rozmów usłyszałam: „Zaciekawiło mnie to co powiedziałaś. Wcześniej nie wiedziałem, że jest coś takiego jak ekologia kulturowa? Sprawdziłem, bardzo ciekawe (...). Z chęcią przeczytam twoją pracę doktorską"3.

Według mnie wymiana informacji, wiedzy i umiejętności w relacji badacz-badany buduje zaufanie po obu stronach. Jak podkreślają w swojej pracy brytyjscy socjologowie Martin Hammersley i Paul Atkinson: „,Jeżeli ktoś nie jest w stanie od samego początku

\footnotetext{
${ }^{3}$ Dziennik badań terenowych, 14.10.2018 r.
} 
wzbudzić zaufania i nawiązać osobistych relacji, opartych na zaufaniu, wtedy dostęp zostanie najprawdopodobniej uniemożliwiony" (Hammersley, Atkinson 2000: 82).

\section{Wnioski}

Wyniki pilotażu dają możliwość usystematyzowania problemów i pytań badawczych. Rozbudowaniu ulegnie kwestionariusz badań. Triangulacja danych, teorii i metod badawczych pozwoli mi wieloaspektowo zbadać współczesne tradycje bartnicze w kontekście ekologii kulturowej i ochrony niematerialnego dziedzictwa kulturowego. Podsumowując wyniki pilotażu stwierdzam, że dalsze penetracje terenowe będą realizowane zgodnie z czterema założeniami badawczymi:

1. współczesne tradycje bartnicze są odtwarzane, adaptowane i upowszechniane przez organizacje bartnicze na potrzeby lokalnych społeczności;

2. wiedza o procesie zmian jakie nastąpił w tradycjach bartniczych; może zostać zastosowana do praktycznych rozwiązań dotyczących kwestii ochrony pszczołowatych i środowiska naturalnego;

3. edukacyjne działania instytucji zajmujących się odtwarzaniem tradycji bartniczych są odpowiedzią na potrzebę podtrzymywania lokalnych tradycji i stają się szansą na kulturalne ożywienie lokalnej społeczności;

4. bartnictwo jest ściśle związane z ekosystemem leśnym, dlatego interakcje między światem ludzi (bartnicy, uczestnicy warsztatów, społeczność lokalna, przedstawiciele samorządów, eksperci, ,ja" jako badacz i uczestnik warsztatów), światem zwierząt (pszczoły i pozostałe zwierzęta leśne korzystające z zasobów barci) a ekosystemem leśnym (puszcza) są rozpatrywane w kontekście współzależności między tymi światami, a także zarządzania zasobami naturalnymi oraz problemu materialności środowiska naturalnego.

\section{Bibliografia}

Armstrong, K.N. (2016). Beeing with Bees: An Anthropological Study on Human-Animal Relations in Southern Beekeeping. The University of Southern Mississippi.

Banaszak, J. (2010). Pszczoły i las. Pszczoła miodna na tle polodowcowej historii lasów w Polsce. Wilczyska: Alegoria.

Banaszak, J. (2012). Pszczoła miodna na ziemiach polskich. Studia Lednickie, 11, 93-113.

Brzezińska, A.W. (2013). Reifikacja dziedzictwa kulturowego w świetle Konwencji UNESCO z 2003 roku. Nauka, 1, 109-128.

Brzezińska, A.W. (2009). Specjaliści od kultury ludowej? Nauka, 3, 155-172. 
Barański, S. (1979). Dzieje bartnictwa w Puszczy Świętokrzyskiej w zarysie. Kielce: Muzeum Narodowe w Kielcach.

Burszta, J. (1954). Znamiona bartne Puszczy Wyszkowskiej. Lud, 41 (1), 530-537.

Ciszek, M. (2009). Środowisko naturalne człowieka jako aktywny czynnik zmiany społecznej. Perspektywa socjologiczno-ekologiczna. Doctrina. Studia Społeczno-Polityczne, 6, 95-99.

Fluehr-Lobban, C. (2014). I Believe in Learning from Bees. This I Believe is Hosted Here in Rhode Island by RI College professor Frederick Reamer. Tune in to FM 88.1 National Public Radio aired this piece Wednesday, March 26. Pozyskano z: http:// ribeekeeper.org/wp-content/uploads/2013/12/I-Believe-in-Learning-from-Bees.pdf.

Grzeszkiewicz-Radulska, K. (2012). Metody badań pilotażowych. Acta Univeritatis Lodziensis. Folia Sociologica, 42, 113-141.

Hammersley M., Atkinson P. (2000). Metody badań terenowych (przeł. S. Dymczyk). Poznań: Wydawnictwo Zysk i S-ka.

Hastrup, K., red. (2014). Anthropology and Nature. New York, London: Routledge.

Hastrup, K (2008). Droga do antropologii. Między doświadczeniem a teorią (przeł. E. Klekot). Kraków: Wydawnictwo Uniwersytetu Jagiellońskiego.

Ingold, T. (2000). The Perception of the Environment: Essays on Livelihood, Dwelling and Skill. London, New York: Routledge.

Kaien, Adom (2016). Powrót do tradycji. W lasach coraz więcej dzikich pszczół. Pozyskano z: https://www.tvp.info/26466985/powrot-do-tradycji-w-lasach-coraz-wiecejdzikich-pszczol.

Kalinowska, K. (2013). Podryw kontrolowany. Rola pracy zespołowej i relacji między badaczami w terenowych badaniach emocji. W: B. Fatyga (red.), Praktyki badawcze (s. 53-68). Warszawa: Instytut Stosowanych Nauk Społecznych UW.

Karpiński, J.J. (1948). Ślady dawnego bartnictwa puszczańskiego na terenie Białowieskiego Parku Narodowego. Kraków: Instytut Badawczy Leśnictwa.

Keczyński, A. O śladach bartnictwa puszczańskiego. Pozyskano z: https://bpn.com.pl/ index.php?option $=$ com_docman\&task $=$ doc_download\&gid $=56 \&$ Itemid $=$.

Keczyński, A. (2017). Z kart historii pszczelarstwa w Puszczy Białowieskiej. Studia i Materiały Ośrodka Kultury Leśnej, 16, 53-80.

Kielak, B. (2004). Historia bartnictwa na Mazowszu. Zeszyty Naukowe Ostrołęckiego Towarzystwa Naukowego, 18, 14-25.

Konczal, A.A. (2017). Antropologia lasu. Leśnicy a percepcja i kształtowanie wizerunków przyrody w Polsce. Poznań: Wydawnictwo Naukowe UAM. 
Konwencja UNESCO w sprawie ochrony niematerialnego dziedzictwa kulturowego z 2003 r. (2003). Pozyskano z: http://niematerialne.nid.pl/Konwencja_UNESCO/ Tekst \%20Konwencji\%20o\%20ochronie\%20dziedzictwa\%20niematerialnego/.

Konwencja w sprawie ochrony światowego dziedzictwa kulturalnego i naturalnego $1976 \mathrm{r}$. (1976). Pozyskano z: http://www.unesco.pl/fileadmin/user_upload/pdf/Konwencja_o_ochronie_swiatowego_dziedzictwa.pdf.

Kuciński, A. (2017). Bartnictwo a uprzywilejowanie ludności w puszczach północnego Mazowsza (XIII-XVIII wiek). Studia Podlaskie, 25, 65-80.

Madras-Majewska, B. (2017). Przywracanie bartnictwa jako szansa ochrony przyrody i staropolskiej tradycji. W: III Ogólnopolska Konferencja „Szanse i wyzwania pszczelarstwa w Polsce" (s. 33-38). Warszawa: Fundacja Edukacji Ekonomicznej i Rozwoju Obszarów Wiejskich.

Nauka w Polsce (2017). Bartnictwo wraca do polskich lasów. Pozyskano z: http://naukawpolsce.pap.pl/aktualnosci/news\%2C $414846 \% 2$ Cbartnictwo-wraca-do-polskich-lasow.html.

Ogródinfo.pl (2017). Wielki powrót barci do polskich lasów. Pozyskano z: https://www. ogrodinfo.pl/aktualnosci/rynki-i-prawo/wielki-powrot-barci-do-polskich-lasow.

Rafacz, J. (1938). Regale bartne na Mazowszu w późniejszym średniowieczu. Lwów: Towarzystwo Naukowe we Lwowie.

Rajagopalan, D.M., Elsner, E. (2017). The Potential of Multiple Perspectives on Beekeeping and Pollinators. Pozyskano z: https://www.envirosociety.org/2017/06/can-wehave-a-moment-please-the-potential-of-multiple-perspectives-on-beekeeping-andpollinators/

Rogoziński, R. (2015). Barć. Augustów: Nadleśnictwo Augustów.

Rysiewicz, M. (2004). Polskie pszczelarstwo A.D 2005. Przegląd Hodowlany, 2, 22-25.

Siudowska-Myzykowa, T. (1960). Materiały do bartnictwa w północno - wschodniej Europie ze szczególnym uwzględnieniem obszaru Polski. Wrocław: Polskie Towarzystwo Ludoznawcze.

Wala, K. (2016). Ułożyć świat na nowo. Rekonstrukcja koncepcji Tima Ingolda (cz. I). Etnologia. Praktyki. Teorie. Doświadczenia, 2, 189-209.

Wróblewski, R. (1987). Święta pszczoła. Kamianna.

Wróblewski, R. (1991). Polskie pszczelarstwo. Wrocław, Warszawa, Kraków: Zakład Narodowy im. Ossolińskich.

Wróblewski, R. (1997). Wierzenia i obyczaje pszczelarzy polskich. Nowy Sącz: Gospodarstwo Pasieczne Sądecki Bartnik. 
Wróblewski, R. (1998). Barcie, kłody, kószki i ule polskie. Nowy Sącz: Gospodarstwo Pasieczne Sądecki Bartnik.

Wróblewski, R. (2009). Krótka historia pszczelarstwa polskiego. Nowy Sącz: Gospodarstwo Pasieczne Sądecki Bartnik.

Żukowski, J. (2011). Wykorzystanie metod jakościowych do badania wiedzy środowiskowej społeczności lokalnych. Journal of Ecology and Health, 15, 1, 7-12.

Żukowski, R. (1965). Bartnictwo w Zagajnicy Łomżyńskiej w okresie od XVI do połowy XIX w. Białystok: Białostockie Towarzystwo Naukowe. 